\title{
MULTI-FAMILY APARTMENTS CONSTRUCTED BETWEEN 1947 AND 2017 IN KOSOVO

\author{
${ }^{1}$ Mimoza SYLEJMANI, ${ }^{2}$ Gabriella MEDVEGY \\ ${ }^{1}$ Department of Architecture, University for Business and Technology, Lagja Kalabria \\ pn 10000, Kosovo, Prishtine, e-mail: mimoza.sylejmani@ubt-uni.net \\ ${ }^{2}$ Department of Architecture, Faculty of Engineering and Information Technology \\ University of Pécs, Boszorkany u. 2, 7624 Pecs, Hungary \\ e-mail; medvegygabriella@mik.pte.hu
}

Received 10 January 2017; accepted 20 October 2017

\begin{abstract}
Since 1947, apartment buildings have made their apparition in the Kosovar city landscape. Different aspects have been highlighted by this extensive research: the different types of architecture and their respective characteristics, the modifications made to them throughout the years and the factors, which contributed to these modifications. These buildings have been divided into two categories, the older buildings built by the public sector from 1947 until 1999 and the recent ones built from 1999 until the present time by the private sector.

Analytical and comparative methods have been used to conduct this research. The results revealed that the living area in apartment buildings built after 1999 has been reduced compared to those built earlier, which implies a general trend of decrease of habitable living space. In addition to this, a change worth mentioning in the functionality of these apartment buildings has been noticed. A survey sent to Kosovar citizens was used in order to obtain their opinions on this subject.
\end{abstract}

Keywords: Collective housing, Living spaces, Trends, Prishtina

\section{Introduction}

Housing represents one of the most important factors that influence social, health stability and in general the quality of human life, it is considered as one of the most important needs for a human being, right after food. The motive and the reasons for the long continuity of housing as an important factor should be sought in the very nature of the human being, the need for socializing, psychological and economic stability, etc. In most countries of the developed world, the housing is a social right for its citizens. Collective housing has a very long tradition and historically is as old as the humanity, 
whereas the housing in multi-apartment, multiple store buildings is linked to the emergence of the high density areas with urban character, with the development of the technology and other factors that have influenced this type of housing. The technology is considered to be result of evolution of the society; it is the attempt to satisfy the needs of society [1].

During the second half of XX century it has been considered that the application of vertical housing represents one of the most effective and logical solutions. In Republic of Kosovo multi-family apartments were constructed in urban areas, first in Prishtina to later continue in other cities, whereby one notices a combination with regard to the organization schemes that were put in use. The design of housing blocks represents one of the most important and suitable solutions regarding contemporary architecture, which at the same time attracts many other challenges regarding social-economic and environmental aspects. The massive construction of buildings in big cities has a big impact on urban aesthetics and individual and collective satisfaction of users [2]. The main purpose of the buildings is to provide to its inhabitants a safe, comfortable and healthy environment where they can perform their various activities ranging from study, leisure and many other activities [3].

The destructions as a result of the War in Kosovo in 1998 and the great need for housing in the period after the war resulted in construction and reconstruction of cities in large scale, thus creating a high density housing with multiple apartments followed by large changes in functional and size aspect (sqm) compared to the buildings that were constructed in earlier periods. Liu Wen Tao emphasizes that people in China regard as a privilege the opportunity of living in the large cities, which are seen as a symbol of being rich and they do not prefer to live in suburbs [4], which is compliant with the mentality of people in Kosovo, as a result of which one observes overpopulation of large cities and a construction of large number of buildings of multifamily apartments, especially in the city of Prishtina.

\section{Objectives}

The purpose of this research is to provide analysis and comparison of the existing multi-family apartments built in various periods of time, and obtaining the opinions of the citizens regarding the aforementioned buildings. The research aims to fill certain gaps in literature regarding the multi-family apartments in Kosovo.

\section{Multi-family apartments in Kosovo}

The housing issue in Kosovo is in a rather grave situation as a result of the war in 1998 and also as a result of poor policies on housing before and after the war.

Based on the investment sector, the construction of multi-family apartments in many countries, no exception to Kosovo is divided into two groups:

- Public sector (Multiple public apartment buildings - Social housing); and

- Private sector (Multiple apartment private buildings). 
In after war period in Kosovo it is the private sector that dominates in the area of construction of multi-family apartments, whereas the public sector is synonymous to social housing. The development of the multi-family apartments in Kosovo can be classified into two groups, in those built in the period 1947-1999 and those after 1999 until now. The period before 1999 is characterized with a construction of large number of multi-family apartments with prefabricated system. Whereas, after 1999 multi-family apartments are built with skeletal system, which has its advantages regarding flexibility. Nevertheless, there is not strong reason for cessation of the process of building prefabricated buildings, given that it is a well-known fact that they meet all the requirements in statics aspects, and the longevity of prefabricated structures resulted in a longer period than it was initially anticipated [5]. In Kosovo little attention is paid to the construction materials, which are used in construction of buildings in general. On the other hand the construction materials play an important role in the performance of the building in the environment [6].

Until 1990 the housing fund had the goal of securing housing units for the citizens who worked in the state institutions and companies. This housing fund, respectively the construction, financing and utilization of housing buildings was a joint contribution of state owned companies and the workers that worked in these companies. For citizens it was not a big problem to secure a housing unit. Socialist period was characterized with green open spaces, parking, children playgrounds and sport playgrounds [7], areas, which in the post-war period in Kosovo has not been paid attention to.

Since 1990 until 1999 the then utilized policies implemented discriminatory laws regarding the housing issue in Kosovo. After the end of war in 1999 in Republic of Kosovo, as a result of population movement from rural into urban areas, the developments in housing sector were out of control and as a result of this the Department of Housing and Construction suffers from lack of information that would help in creation of long-term plans for the development in the area of housing as well as that of construction.

After 1999 in Kosovo the development of housing sector was mostly done by the private sector and this situation was followed by irregularities and lack of criterions. Securing the sufficient space for housing became one of the most pressing challenges in Kosovo. The requirement for housing increased in a very large scale, however it varies from region to region. The number of young families in Kosovo is rather large. These young families do not have the possibility to secure with their incomes appropriate housing units as a result of high cost of these apartments, a cost that is considered to be one of the highest in the region. The price of apartment represents one of the most important elements, which indicates if people can deal with the price of housing or not [4]. On the other hand the scale of unemployment represents one of the most pressing social and economic problems. Various sources consider that the present scale of unemployment is $50-55 \%$ and that the largest proportion of unemployment is to be found among young people and women [8, p. 113]. Table I shows the degree of poverty in Kosovo compared to the region.

All this influenced on the issue that housing units constructed after 1999 are followed by many changes, especially in terms of size in sqm, and also in functional aspect. It is very important that one performs the Post Occupancy Evaluation (POE), the 
latter deals mostly with the functional aspects, respectively with the experiences and the requirements of the people that utilize certain building in daily basis [9].

\section{Table I}

The degree of poverty in Kosovo compared to the region

Source: Spatial Plan of Kosovo - The strategy of spatial development 2010-2020, translated by the author $[8$, p. 111]

\begin{tabular}{|c|c|c|c|c|c|c|}
\hline & $\begin{array}{c}\text { Serbia and } \\
\text { Montenegro }\end{array}$ & Macedonia & Bulgaria & Albania & Romania & Kosovo \\
\hline Scale & $30 \%$ & $24 \%$ & $12.6 \%$ & $30 \%$ & $44.5 \%$ & $50.3 \%$ \\
\hline
\end{tabular}

The responsible institutions for regulation of housing and construction sector in Kosovo are: Department of Housing and Construction in Ministry of Environment and Spatial Planning, the Department of Construction in the Ministry of Trade and Industry in central level, whereas in local level it is the Directorates of Urbanism.

\section{Research methodology}

The research methodology for this paper is presented in Fig. 1 .

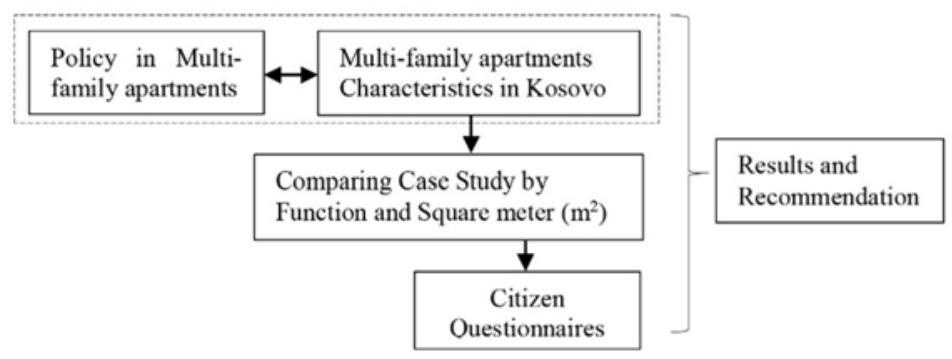

Fig. 1. Research model

The first part deals with the policy in multi-family apartments in Kosovo, the second part deals with the analysis of these buildings, the changes that occurred with passing of time, and the third part deals with the questionnaires that were distributed to the citizens. During the research the analysis of the multi-family apartments is treated, which were selected as case study (Fig. 2) both in functional aspect and in terms of size of the flat that were constructed in various time periods. The division in two groups was done given that the multifamily apartments constructed before 1999 were constructed by the public sector, whereas those after 1999 by the private sector.

In addition, one questionnaire was distributed to the citizens in order to obtain their opinion on these buildings. The Sample Size for the questionnaire survey is determined using Sample Size Calculator [10], whereby for the population over eighteen years of age, which represents 1.077.316 individuals [11], the size of the sample was 600. In 
order to increase the degree of precision during this survey, the size of the sample was taken 800 .

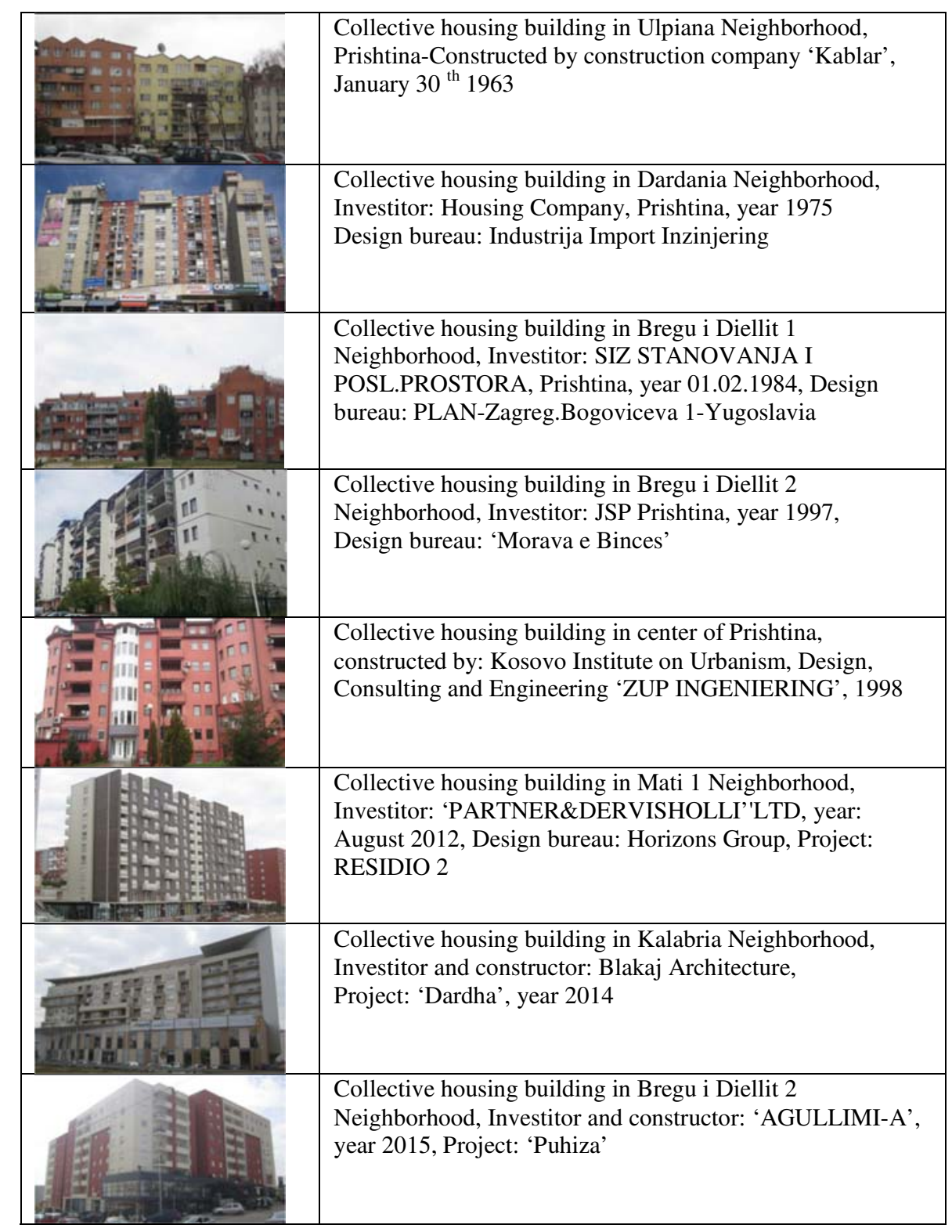

Fig. 2. Multi-family apartments constructed in the different time periods, case study in Prishtina

Fig. 2 shows multi-family apartments constructed in different time periods, which were took as a case study during analysis of living spaces. 
I) In the period before 1999 in housing units one defined clearly the calm area from the noisy part. The kitchen was divided from the living room and one observed no lack of utilities. The living surface of these buildings was in compliance with JUS standard, and the inhabitants of these housing units would obtain these flats from the companies where they were working for with a favorable price (Fig. 3).

II) After 1999 in most cases there was no clear distinction between calm area and noisy one in multi-family apartments, the utility spaces are missing and the surface of the flats has significantly decreased in terms of available floor compared to the buildings that were constructed in earlier period. The citizens can barely deal with the prices of the flats which are now being built by the private sector (Fig. 4).

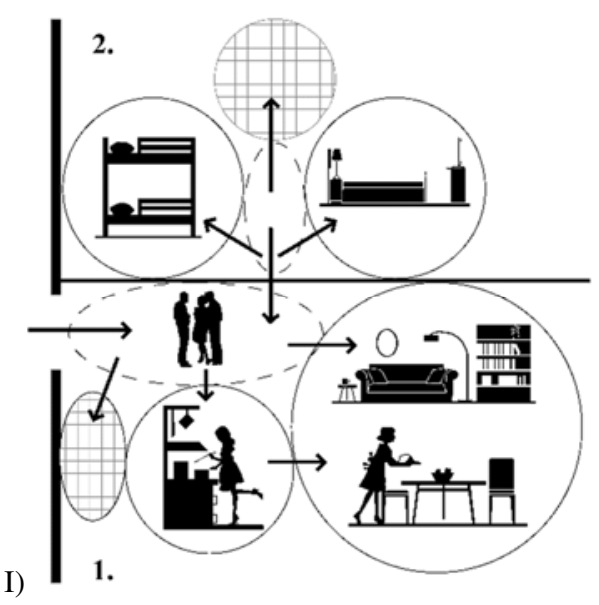

Fig. 3. Development of the concept of multi-family apartments before year 1999

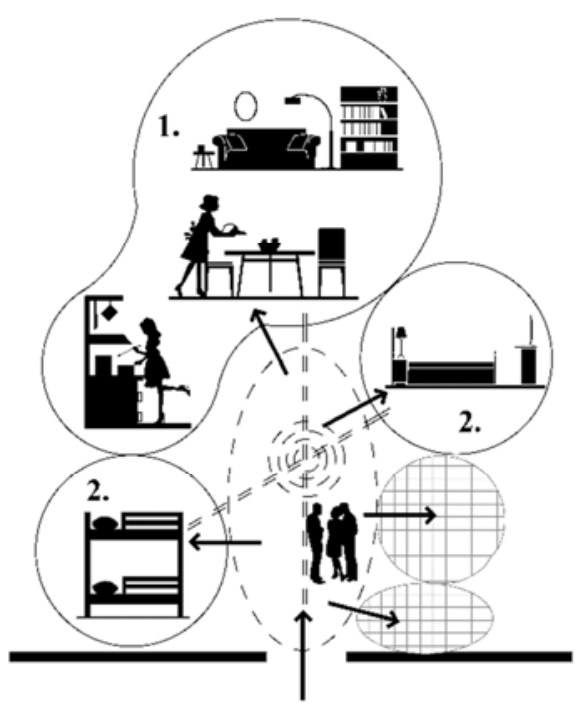

Fig. 4. Development of the concept of multi-family apartments after 1999

Fig. 5 shows the diagrams of the floor area, in one-, two- and three-room apartments, constructed in different time periods.

\subsection{The questionnaires given to the citizens}

In order to better understand the opinion of the citizens regarding the multi-family apartments constructed in the past and those constructed recently, one distributed questionnaires to over 800 random citizens over 18 year old in various cities of Kosovo. The questionnaire consisted of eleven different questions regarding the mentioned buildings Fig. 6 - Fig. 14. 


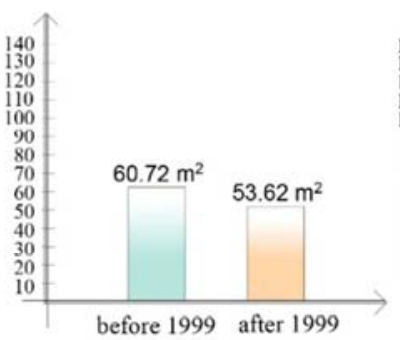

a)

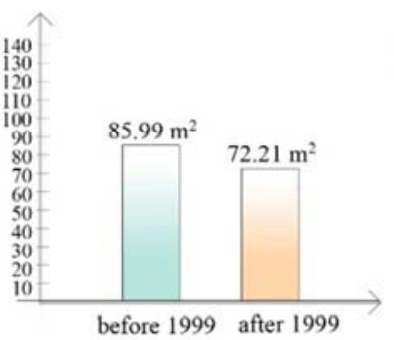

b)

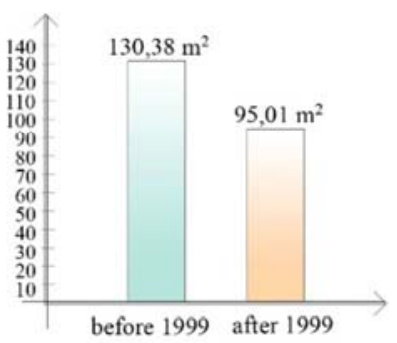

c)

Fig. 5. The diagrams of the floor area: a) one-room; b) two-rooms and c) three-rooms

- Where do you prefer to live (Fig. 6)?
a) In the center of the city;
b) In the suburbs of the city;
c) In the village.

- Where do you prefer to live (Fig. 7)?

a) Multi apartment building (apartment);

b) House;

c) Other.
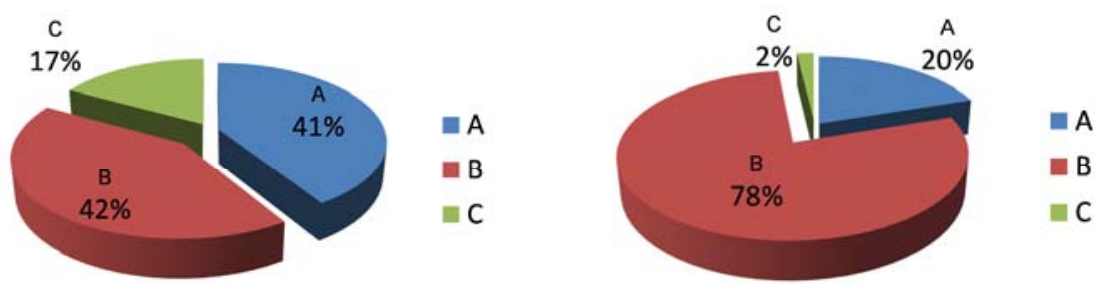

Fig. 6. The result for question: Where do you prefer to live?

Fig. 7. The result for regarding type of building

- What floor do you prefer to live in (Fig. 8)?

- How many rooms would you prefer your apartment would have (Fig. 9)?

- The area (room) which is mostly used in the building you reside in (Fig. 10)?

- What do you think the surface area should be?
a) Studio apartment
$41.5 \mathrm{~m}^{2}$;
b) Of one room apartment
$64.7 \mathrm{~m}^{2}$
c) Of two room apartment
$91 \mathrm{~m}^{2}$. 

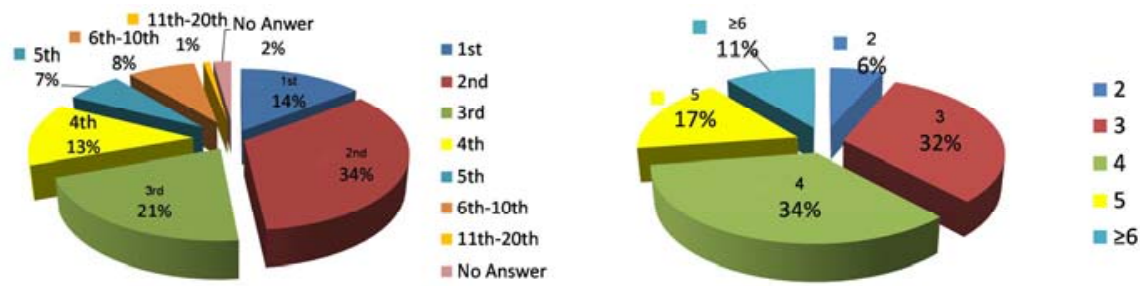

Fig. 8. The result for question: What floor do you prefer to live in?

Fig. 9. The result for regarding number of rooms

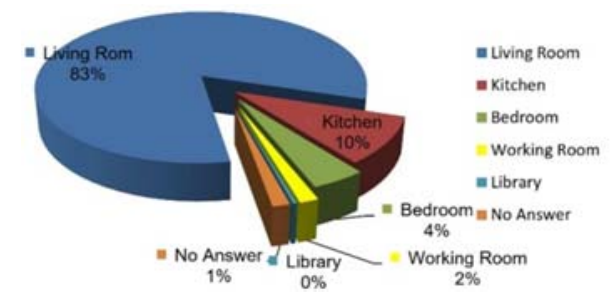

Fig. 10. The result for question: The area which is mostly used in the building you reside in?

- How many apartments do you prefer to be in one floor (Fig. 11)?

- What use do you prefer the ground floor to be for (Fig. 12)?

- What type of area lacks in the buildings constructed recently in our country? Children playground, parking, parks, storages, utilities, elevators.

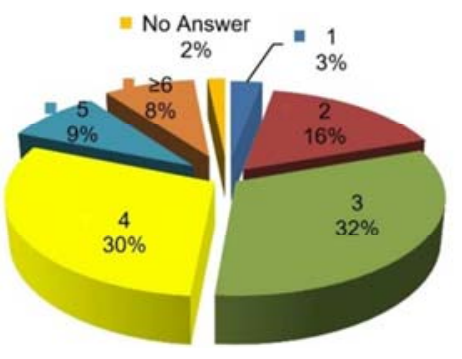

Fig. 11. The result for question; How many apartments do you prefer to be in one floor?

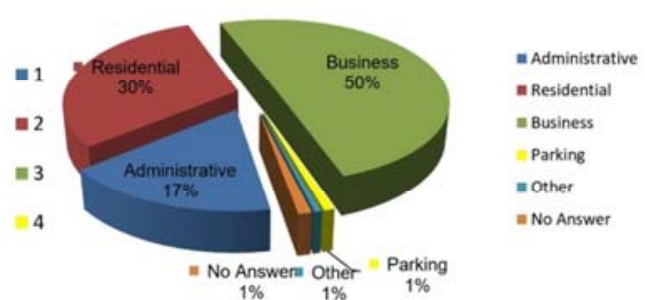

Fig. 12. The result for question: What use do you prefer the ground floor to be for?

- Do you prefer to have the kitchen separated from the living room, or within it (Fig. 13)?

a) Separated from living room;

b) Within the living room.

- Do you prefer the multi apartment buildings constructed before or after the war (Fig. 14)? 
a) The buildings constructed before the war (1980-1999);

b) The buildings constructed after the war (2000-today);

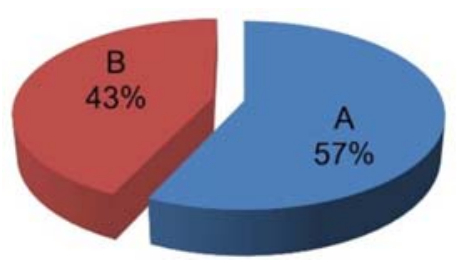

Fig. 13. The result for question; Do you prefer to have the kitchen separated from the living room, or within it?

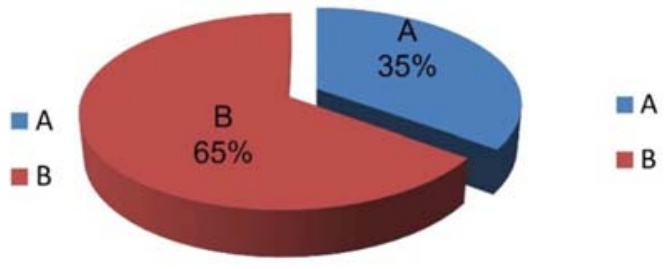

Fig. 14. The result for question: Do you prefer the multi apartment buildings constructed before or after the war?

\section{Result and discussion}

Based on the results, it can conclude that the trends in Kosovo have moved towards decreasing of the living area size. The results indicate that this surface has decreased more in the three room flats. In order to utilize the surface in the most rationale manner it comes to the changes in functional aspect, by integrating the kitchen with the living room, thus eliminating the utility spaces and in a major part of the cases interweaving the calm areas with the noisy ones within the apartment unit. In order to create the feeling of larger areas, these living units with smaller surfaces should be treated in a more serious manner and not only horizontal direction, but also in vertical one. Of major importance is the use of appropriate materials, the lighting and transparency in architectural space [12]. The best way to follow would be if the developers would cooperate with the buyers, this would help especially the people with low and median incomes, thus enabling them to put cheaper materials in living units thus lowering the cost of their apartment. This issue would pose its advantages given that it would enable living within the same apartment complex of the people with different incomes and thus eliminating the discrimination between various social classes.

\section{Conclusions}

The decrease of living space came about as a result of the economic conditions, respectively of prevalent unemployment rate, which Kosovo struggles with. During socialist system securing the living units was not a big problem, given that the employees in the various organizations had the possibility to obtain apartments with favorable prices. Nowadays, in capitalist system the price of apartment units is rather high and it is difficult for citizens of Kosovo to overcome this challenge.

The budget funds of Government of Republic of Kosovo are rather limited; therefore it is impossible for the Government to secure housing units for its less affluent citizens who have no financial means to secure their own housing. The problem does not rest 
only on this issue. The private banks are not involved in the investments in housing as a result of lack of credibility, however, even in the cases where they get involved the interest rate they provide is so high and maturation so short, that it can hardly be overcome by the citizens. On the other hand the Government does not have instruments to control the prices of the flats that not are constructed by the private sector.

The problems that are faced by the housing sector in Kosovo can be characterized in different aspects as:

- Legal Aspect: lack of laws, regulations and policies in the area of construction;

- Social Aspect: Lack of suitable apartments, construction of buildings for social cases - families with low incomes;

- Financial Aspect: The Government does not have sufficient funds for construction of those buildings;

- Spatial Aspect: Irrational use of construction land and lack of supporting infrastructure.

\section{References}

[1] Hăramănescu M., Enache C. Vernacular and technology, Procedia Environmental Sciences, Vol. 32, 2016, pp. 412-419.

[2] Dinçer A. E., Çağdaş G., Tong H. A computational model for mass housing design as a decision-support tool, Procedia Environmental Sciences, Vol. 22, 2014, pp. 270-279.

[3] Ibem E. O., Opoko A. P., Adeboye A. B., Amole D. Performance evaluation of residential buildings in public housing estates in Ogun State, Nigeria: Users' satisfaction perspective, Frontiers of Architectural Research, Vol. 2, No. 2, 2013, pp. 178-190.

[4] Tao L. W., Living conditions - The key issue of housing development in Beijing Fengtai District, HBRC Journal, Vol. 11, No. 1, 2015, pp. 136-142.

[5] Borsos A. Living spaces-prefabricated apartments, Pollack Periodica, Vol. 9, No. 2, 2014, pp. 59-66.

[6] Porhincak M., Estokova A., Vilcekova S. Comparision of environmental impact of building materials of three residental buildings, Pollack Periodica, Vol. 6, No. 3, 2011, pp. 53-62.

[7] Kristiánová K. Post-socialist transformations of green open spaces in large scale socialist housing estates in Slovakia, Procedia Engineering, Vol. 161, 2016, pp.1863-1867.

[8] Spatial plan of Kosovo - Spatial Development Strategy 2010-2020 (in Albanian) Ministria e Mjedisit dhe Planifikimit Hapesinor, Prishtine, June, 2010.

[9] Van der Voordt T. J. M., Van Wegen H.B. R. Architecure in use: An introduction to the programming, design and evaluation of buildings, Elsevier, 2005.

[10] Creative Resarch Systems, https://www.surveysystem.com/sscalc.htm, (last visited 30 December 2016).

[11] The registration data of population and their impact in public policy, (in Albanian) Institute for Advanced Studies, October 2012, p. 10, http://www.institutigap.org/documents/67092 _GAPanalizepertedhenateASK.pdf (alst visited 30 December 2016).

[12] Medvegy G. Architectural space-transitions of the floor plan of design projects, in International Conference on Research and Education Challenges Towards the Future, Albania, Shkoder, 30-31 May 2014, p. 209. 